\title{
English Lecturers' Competencies and Readiness towards Teaching Writing Using Flipped Learning Approach: A Formation of Theoretical Framework
}

\author{
Farah Idayu Mohd Salleh ${ }^{1,2, *}$, Sarimah Shamsudin², Harmi Izzuan Baharum², Jamilahtun Md \\ Ghazali $^{1}$, Syazwa Nabila Mohd Raidzuan ${ }^{1}$ \\ ${ }^{1}$ University Kuala Lumpur - Malaysian Institute of Industrial Technology (UniKL MITEC), Johor, Malaysia \\ ${ }^{2}$ Universiti Teknologi Malaysia Kuala Lumpur (UTM KL), Kuala Lumpur, Malaysia
}

Received June 29, 2019; Revised October 30, 2019; Accepted November 6, 2019

Copyright $\bigcirc 2020$ by authors, all rights reserved. Authors agree that this article remains permanently open access under the terms of the Creative Commons Attribution License 4.0 International License

\begin{abstract}
This conceptual paper describes the formation of theoretical framework for flipped learning competencies and readiness among English lecturers. This paper has been divided into several categories such as introduction, background of the study, the objectives of the research, theoretical framework and conclusion. From the study, it can be seen that there is one theory and one model that has been used in this study such as Theory of Planned Behavior and Technology Acceptance Model (TAM). As this research not covering all 4 main models of blended learning, future research can be focused on the whole model of blended learning from various aspects.
\end{abstract}

Keywords Universiti Kuala Lumpur, Flipped Learning, Competencies, Readiness

\section{Introduction}

According to [1], writing is a way of sharing information, thoughts, ideas and experiences in a written form. [2] believes that writing is the mental work of inventing ideas and organizing the words into statements and paragraphs that will be clear to the reader. In language learning, passive skills consist of listening and reading, whereas active skills include speaking and writing. Teaching writing is a complex process that needs a cooperative learning situation [3]. [3] also said that "the atmosphere of writing classroom should be warm, supportive and non-threatening." It means that in the teaching of writing skills, the lecturer should involve the learners in interesting activities. Besides, English lecturers have a duty to ensure the students obtain the skills that they need to flourish in student-centered environment. To overcome English lecturers' difficulties in the teaching of writing skill, flipping would be used in this study. Flipped learning involves much more than adding the technology and out-of-class video activities into the curriculum; it also requires both teachers and students to 'flip' the way they view the education [4]. Therefore this study will look at English lecturers' competencies and readiness in the teaching of writing skill using flipped learning. According to [5], readiness related to teachers' awareness, knowledge of use, perceptions and attitudes towards their skills and capabilities for technology integration as well as their experience in the use of educational technology.

Teaching of English in Malaysia has been introduced by the British colonial education system in the 1960s and now it is established in the current Malaysian educational system [6]. As a result, English is taught as a second language in all Malaysian schools and it is also a compulsory subject in both primary and secondary schools. Based on [7] at the tertiary level, all local undergraduates are required to register a compulsory credit hour of English based on their result of Malaysian University English Test (MUET), and MUET also is a compulsory requirement for the students who wish to pursue tertiary education at Malaysia universities.

According to the study by [8], English as Second Language (ESL) teachers in Malaysia face the problems in teaching writing, especially those related to conventions and punctuation. [8] in their study also state that lack of English language proficiency is the main cause of difficulties that ESL learners face in their writing tasks. [9] in his study states that ESL students are also disappointed with difficulties in understanding word implication and meaning.

In the same way, most English as Second Language (ESL) learners face many problems in learning writing [1]. 
The problems include having difficulty in developing and organizing ideas well, lack of vocabulary, having difficulty with grammar structures including mechanics of writing, not interested in the writing topics, not receive feedback from the teacher due to limited time in the classroom, not enough materials for writing, and feel bored and less motivated to do writing [1].

[10], states that the difficulties in writing are not only in generating and organizing the ideas, but also in translating these ideas into readable text. Those difficulties make the students feel less confident in writing. [11] cited the problems faced by ESL teachers in teaching writing such as first, dealing with the teaching of the less proficient students. These students prefer to use ineffective writing strategies and the teachers struggle to teach them on how to write. Second, teachers have to deal with students' negative attitude towards writing. Most of them lack confidence in themselves as writers. Lastly, not receiving immediate feedback from teachers on their writing product, it is because students have limited time to consult, get comment and feedback from their teacher.

To overcome teachers' difficulties in teaching writing skill, flipped learning would be used in this study. Through flipped learning, the teacher can provide materials, assign the task through video and ask the students to watch the video before coming to the classroom [11]. [12] suggests that flipped learning promotes an environment which increases the interaction between students and the teacher. In flipped learning, it focuses more on student-centered rather than teacher-centered learning. As explained by [13], flipped learning promotes personalized learning as students can pause, re-wind, and re-watch the online video at their own pace.

[14] proposes that flipped learning is using technology to deliver asynchronous direct instruction with the intention of freeing up class time for student-centered learning. Whereas [15] mentions that flipped learning is a teaching method that delivers lecture content to the students via electronic medium and teachers can use class time for practical application activities.

For centuries, most higher learning institutions have been using classroom-based learning to deliver teaching and learning. In a traditional setting classroom, it focuses more on lecturer-centred. Over the past few years, the learning institutions have been undergoing changes. These changes include a larger population of learners from varied backgrounds, needs, motivations, abilities, learning preferences, time availability and course content requirements [16]. The results of the studies by [17] and [18] suggested that technology in education helps the teachers to foster and support certain learning activities, but this occurs only when effective use of online resources and tools is taken into account so that the technology in education is effectively integrated into the teaching and learning process.
Currently, in Malaysia, the implementation of technology in education has captured great interest not only of the teachers, but also of the students in higher education institutions. According to [19], Technology-Enhanced Learning (TEL) means bringing the knowledge closer and making it more accessible to everyone. [20] believed that there are many opportunities for students to gain confidence in practicing and improving themselves, especially for ESL students who learn the language more than just for fun. To make the students keep pace with TEL and gain more confidence, they have to stride into the world of multimedia technology.

To sum up, teaching writing is a complex process [3]. Based on a study by [8], most of ESL teachers in Malaysia face the problems in teaching writing, especially when it comes to conventions and punctuation. Hence, to overcome this problem, flipping would be used in this study. Flipped learning focuses on student-centred learning by using technology to deliver the instruction outside the classroom. By using flipped learning in writing classroom, students will be able to practice in collaborative activity, peer instruction or feedback, project-based learning or creative project [1]. In short, this study will look at English lecturers' competencies and readiness in the teaching of writing skill using flipped learning.

\section{Background of the Study}

According to [21], writing is a productive skill, where it shares some functional characteristics with speaking but it also displays unique elements which are not common to both. Teaching writing is something challenging especially for ESL teachers as students have different proficiency level in a classroom. To overcome this issue, flipped learning would be used in this study. Currently, students learn writing by doing exercises and listening to the teacher passively. Therefore, in order to cater to the students' needs who learn differently, teachers should consider adjusting their pedagogical approach and creating better learning environments that suits different levels of learners. [21] also believes that writing is a skill that even most native speakers can never master because it requires the production of a long, coherent and fluent piece of writing.

In addition, most of the students find writing as something difficult rather than the other skills like reading, listening and speaking. [21] believes that writing is a skill, like reading, which has to be taught. $\mathrm{He}$ also acknowledges that "for second language learners the challenges are enormous" [21]. Based on a study by [22], even though writing is an essential skill, most of high school students are not interested in it. [23] believes that there are many students who never required learning 
proper spelling or grammar. These students then come to think that "English" and "writing" are nothing except for spelling and grammar. These students are also not aware of the importance of writing skill in their learning. As a result, these students often have many basic mistakes in their written works like spelling, grammar, punctuation and organization.

\section{The Objectives of the Research}

(i) To study on how flipped learning could be used to teach writing skills.

(ii) To identify the competencies needed in the teaching of writing skill to implement flipped learning among English lecturers.

\section{Theoretical Framework}

This part discusses the theoretical framework used in this study. According to Flipped Learning Network (FLN, 2014), there are four pillars that the teachers or lecturers must incorporate into their practice when they implement flipped learning in their teaching which are flexible environment, learning culture, intentional content and professional educator.

In flexible environment, teachers create flexible spaces where the students make their choice about when and where they will learn. Learning culture in flipped learning means classroom time is dedicated to explore the topics in greater depth and creating rich learning opportunities. It will make the students more active in knowledge construction as they are participants and they are also evaluating their learning in a manner that is personally meaningful to them. Subsequently, intentional content in flipped learning means flipped learning educators or the teachers determine what they need to teach and what materials students should handle on their own. By using intentional content, educators will maximise classroom time in order to adopt methods of student-centred, and to enhance active learning strategies depending on the grade level and subject matter. Next is professional educator, where the role of professional educator is very important in a flipped learning than in traditional approach. During class time, they need to observe students, providing them with instant feedback and assess students' work. As a result, the group learning space is transformed into a dynamic and interactive learning environment where the educator plays an important role to guide the students as they apply the concepts and engage creatively in the subject matter. It means that when the teacher use flipped learning approach, they automatically enhance students' self-learning as teachers act as an observer in the classroom. Besides that, students will become active learner in the classroom as they are responsible for their learning.
There is one theory and one model that will be used for this study. (24), states that the Theory of Planned Behaviour predicts an individual's intention to engage in behaviour at a specific time and place. He also believes that human behaviour has been guided by three factors such as beliefs about the likely consequences of the behaviour (behavioural beliefs), beliefs about the normative expectations of others (normative beliefs), and beliefs about the presence of factors that may facilitate or block performance of the behaviour (control beliefs) (24). In behavioural beliefs, it produces either a favourable or unfavourable attitude towards the behaviour. Unlike the behavioural beliefs, normative beliefs refer to perceived social pressure or in other words, subjective norm, where control beliefs give rise to perceived behavioural control. When we combine all these factors, it shows that the more favourable the attitude and subjective norm, together with the greater perceived control, the stronger should be the person's intention to perform the behaviour (24).

Meanwhile, Technology Acceptance Model (TAM) is an information theory that shows how users come to accept and use a technology [2]. In this model, it suggests that when users are presented with the new technology, there are factors such as perceived usefulness and perceived ease-of-use that influence their decision about how and when they will use it.

[2], in his book What Teachers Should Know and Be Able To Do explains that effective teachers in all content areas should mastering all three elements such as the reader, the text and the learning situation. According to [2], effective teachers should understand that students' abilities affect their writing performance, and students' knowledge of spelling and conventions of writing may influence their performance on writing tasks. Besides that, effective teachers should understand the importance of planning, revision and editing processes, and also a feedback from the teacher and peers in developing students' writing skill. This is to improve students' written products. The effective teachers also should foster motivation to the students to read and write independently.

Based on [2], flipped learning is a pedagogical approach that changes the instruction from the group learning space to the individual learning space by using four pillars of F-L-I-P which are flexible environment, learning culture, intentional content and professional educator. As a result, the group learning space is transformed into a dynamic and interactive learning environment where the educator plays an important role to guide the students as they apply the concepts and engage creatively in the subject matter. It means that when the teacher uses flipped learning approach, they automatically enhance students' self-learning as teachers act as an observer in the classroom. Besides that, students will become active learners in the classroom as they are responsible for their learning. 
In addition, English lecturers' readiness plays an important role in the use of flipped learning in the teaching of writing skill. According to [2], teachers need sufficient skills to implement technology into their teaching and they also need to have high confident level to use it in a classroom setting. Meanwhile, [] believes that teachers who have gone through training are more effective in teaching using technology tools compared to those who have no experience in such training.

Another essential point, based on TAM, the user which is English lecturers will use the technology in their teaching when they think that the technology is useful and can enhance their teaching skill. Readiness based on [30] refers to "people tendency to use the technology to accomplish their goals at home or at the workplace." They believed that a person's perception of the technology has a positive and a negative side. This shows that acceptance and readiness are two different things. In this study, English lecturers might accept the use of flipped learning in their teaching because they think it will enhance their teaching of writing skill, but they may not be ready to implement it because of the factors that hinder them to use flipped learning in their teaching.

To sum up, according to the Four Pillars of Flipped Learning, Theory of Planned Behaviour and Technology Acceptance Model, this study focuses on the competencies and the readiness in the teaching of writing skill using flipped learning approach. Figure 1 below shows theoretical framework of this study.

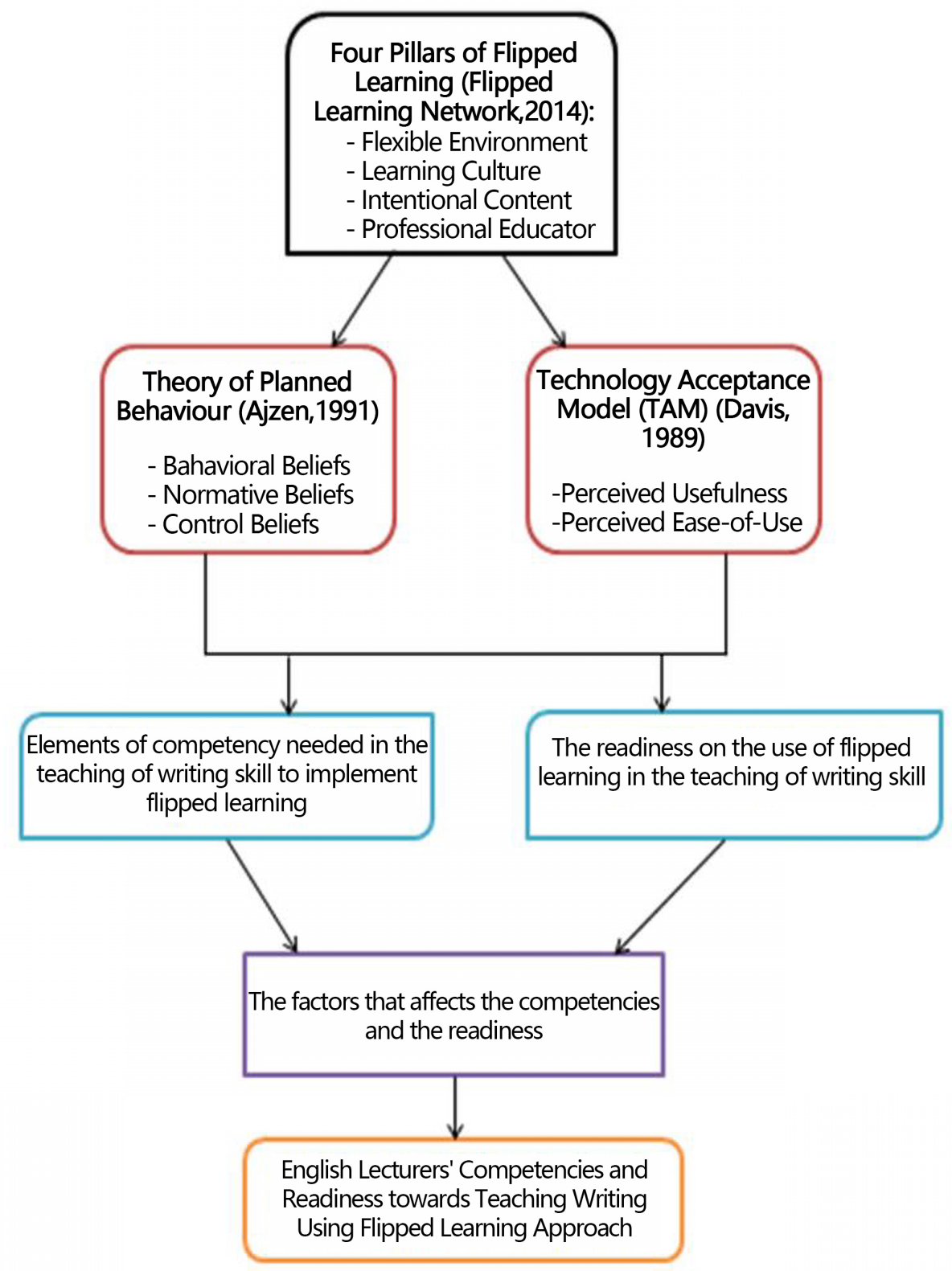




\section{Conclusions}

In this study, UniKL English lecturers' competencies and readiness in the teaching of writing skill using flipped learning approach will be studied. For that reason, teaching writing skill through flipped learning approach has advantages and disadvantages. Furthermore, there are one theory and one model that will be used for this study which are Theory of Planned Behaviour and Technology Acceptance Model (TAM). To sum up, it is hoped that the outcome of this study will help the English lecturers to explore ways and means of creating a better teaching writing skill using flipped learning approach.

\section{Acknowledgements}

The author would like to thank Short Term Research Grant (STRG) Universiti Kuala Lumpur who offers a fund to conduct this study.

\section{REFERENCES}

[1] Khoiriyah, \& Mahendra Puji Permana Aji, Promoting Flipped Classroom Model in Teaching Writing of EFL Learners. The 4th International Conference on Language, Society and Culture in Asian Contexts (LSCAC), 279-291. doi:10.18502/kss.v1i3.748, 2017.

[2] Nunan D, Practical language teaching. New York McGraw Hill Company, 2003

[3] Nunan D, Language teaching methodology: A textbook for teachers. Great Britain, 1991.

[4] Mervat Abd Elfatah Ali Said Ahmed, The Effect of a Flipping Classroom on Writing Skill in English as a Foreign Language and Students' Attitude Towards Flipping. US-China Foreign Language, 14(2), 98-114. doi:10.17265/1539- 8080/2016.02.003, 2016.

[5] Msila, V. Teacher readiness and information and communications technology (ICT) use in classrooms: A South African Case Study. Creative Education, 6, 1973-1981. 2015, Retrieved from http://dx.doi.org/10.4236/ce.2015.618202

[6] Asmah Haji Omar, "The Linguistic Scenery in Malaysia”, Dewan Bahasa dan Pustaka. Kuala Lumpur, 1992.

[7] Malaysian Examination Council, "Malaysian University English Test (MUET)”, Kuala Lumpur, 2006.

[8] Ghabool, N., Mariadass, M. A., \& Kashef, S, Investigating Malaysian ESL Students' Writing Problems on Conventions, Punctuation, and Language Use at Secondary School Level. Journal of Studies in Education, 2, 3rd ser., 130-143. doi:10.5296/jse.v2i3.1892, 2012.

[9] Leki, I, ESL composing: Strategies and perceptions. In B. Leeds (Eds.), Writing in a Second Language: Insights from First and Second Language Teaching and Research.
Longman: Addison-Wesley, 1992.

[10] Richards J. C., Renandya W. A, Methodology in Language Teaching. Cambridge University Press Cambridge DOI: 10.1017/CBO9780511667190, 2002.

[11] Gebhard J. G, Teaching English as a foreign or second language. Ann Arbor: The University of Michigan Press, 1996.

[12] Sams A, The flipped class: Shedding light on the confusion, critique, and hype. The Daily Rift. Retrieved from http://www.thedailyriff.com/articles/the-flipped-class-shed ding- light-on-the-confusion-critique-and-hype-801.php, 2011.

[13] Gerstein, J, The Flipped Classroom Model: A Full Picture. Retrieved January 15, 2015, from http://usergeneratededucation.wordpress.com/2011/06/13/t he- flipped-classroom-model-a-full-picture, 2011.

[14] Cockrum T, Flipping your English. New York: Routledge, 2014.

[15] Arnold-Garza S, The flipped classroom teaching model and its use for information literacy instruction. Communication in Information Literacy. Volume: 8 (1), 2014.

[16] Phillips, R, Challenging the primacy of lectures: The dissonance between theory and practice in university teaching. Journal of University Teaching and Learning Practice, 2(1), 1-12, 2005.

[17] Wenglinsky, H, Does it compute? The relationship between educational technology and student achievement in mathematics. Princeton, NJ: Policy Information Center, Educational Testing Services, 1998.

[18] Cradler, J., McNabb, M., Freeman, M., \& Burchett, R, How does technology influence student learning?. Learning and Leading with Technology, 29(8), 46-49, 2002.

[19] Farahiza Zaihan Azizan, Blended learning in higher education institution in Malaysia.in Proceedings of Regional Conference on Knowledge Integration in ICT (pp. 454-466), 2010.

[20] Solanki D. Shyamlee., \& M. Phil, 2012 International Conference on Language, Medias and Culture (IPEDR vol.33 (2012)). IACSIT Press, Singapore, 2012.

[21] Nunan, D, Second Language Teaching and Learning. Boston: Heinle \& Heinle Publishers, 1999.

[22] Nguyen Thanh Huy, Problems Affecting Learning Writing Skill of Grade 11 at Thong Linh High School. Asian Journal of Educational Research, 3(2), 53-69. Retrieved January 17, 2018, from http://www.multidisciplinaryjournals.com/wpcontent/uploads/2015/03/Problems-Affecting-Learning-Wr iting- Skill-Of-Grade-11.Pdf, 2015.

[23] Robert Todd Carroll, Student Success Guide: Study Skills. www.skepdic.com/refuge/studyskills1.pdf, 1990.

[24] Ajzen, I, The theory of planned behavior. Organizational Behavior and Human Decision Processes, 50(2), 179-211, 1991.

[25] Davis, F, Perceived usefulness, perceived ease of use, and user acceptance of information technology. 13(3), 319-340, 
1989.

[26] Shulman, L. S., \& Sykes, G, Handbook of teaching and policy (2nd ed.). New York: Longman, 2015.

[27] Flip Learning Network (FLN), FLN Shares its Four Pillars of Flipped Learning. Retrieved November 22, 2017, from https://thejournal.com/articles/2014/03/12/fln-announces-f ormal-definition-and-four-pillars.aspx, 2014, December 3.

[28] Hennessy, S., Ruthven, K., \& Brindley, S, Teacher perspectives on integrating ICT into subject teaching: commitment, constraints, caution, and change. Journal of Curriculum Studies, 37(2), 155-192. doi:https://doi.org/10. 1080/0022027032000276961, 2007.

[29] Winzenried, A., Dalgarno, B., \& Tinkler, J, The Interactive Whiteboard: A transitional technology supporting diverse teaching practices. Australasian Journal of Educational Technology, 26 (Special Issue 4), 534-552, 2010.

[30] Ling and Moi. "Professional students' technology readiness, prior computing experience and acceptance of an e-Learning System", Malaysian Accounting Review, 2007 6(1): p. 85-99 